Cahiers $d u$ MONDE RUSSE

\section{Cahiers du monde russe}

Russie - Empire russe - Union soviétique et États indépendants

$57 / 4 \mid 2016$

Varia

\title{
Narrating the Time of Troubles in Polish School History Textbooks (1918-1989)
}

Le Temps des Troubles dans les manuels d'histoire polonais (1918-1989)

\section{Machteld Venken}

\section{OpenEdition}

\section{Journals}

Electronic version

URL: http://journals.openedition.org/monderusse/9996

DOI: 10.4000/monderusse.9996

ISSN: $1777-5388$

\section{Publisher}

Éditions de l'EHESS

\section{Printed version}

Date of publication: 1 October 2016

Number of pages: $879-902$

ISBN: 978-2-7132-2542-0

ISSN: $1252-6576$

Electronic reference

Machteld Venken, « Narrating the Time of Troubles in Polish School History Textbooks (1918-1989)», Cahiers du monde russe [Online], 57/4 | 2016, Online since 01 October 2018, Connection on 05 January 2020. URL : http://journals.openedition.org/monderusse/9996; DOI : 10.4000/monderusse.9996 


\section{NARRATING THE TIME OF TROUBLES IN POLISH SCHOOL HISTORY TEXTBOOKS (1918-1989)}

The crisis that jolted Central and Eastern Europe at the beginning of the seventeenth century has been interpreted as an important Russian-Polish conflict. Ever since the death of Tsar Boris Godunov in 1605, Muscovy had been suffering from a dynastic crisis. It was divided by civil war and had been invaded by Sweden and the Polish-Lithuanian Commonwealth. In 1610, the elected Polish king, Sigismund III Vasa, caused uproar in Russia by installing his son Ladislaus on the Moscow throne. In 1612, the Russians succeeded in defeating the army of the Commonwealth. In the following year, they chose a new tsar, Mikhail Romanov, who established a new dynasty that was to rule the country for more than three centuries.

During the nineteenth and twentieth centuries, this Smuta, as the Time of Troubles is called in Russian, has been overshadowed by other crises, such as the Polish partitions at the end of the eighteenth century, Napoleon's expedition to Russia, the First and Second World Wars, and the Cold War. Yet its place in recent Russian and Polish memory should not be underestimated. In 2005, Putin introduced a new national holiday on 4 November to commemorate the end of foreign intervention in Russia. In 2007, the feature film 1612: Chronicles of the Time of Troubles by Vladimir Khotinenko was released. Commissioned by the government, it was intended to mobilize society for the approaching presidential election in 2008 by paralleling contemporary Russia before Putin and the Time of Troubles as two historical moments characterized by an absence of state governance. The film argues that a strong central power is needed in order to keep external forces out, and portrays Polish noblemen as Russia's historical arch-enemies. In a book published with the support of the Russian Ministry of Culture, Druz'ia i vragi Rossii: Karmannyi slovar', the Russian philosopher Roman Svetlov presents Polish noblemen as the nation's most frequent enemy, responsible for the deaths of more Russians than occurred as a result of the Mongolian attacks. ${ }^{1}$

I started to work on this article while being a Lise Meitner Fellow and finished it while holding an Elise Richter Grant. The research was kindly supported by the Austrian 
The Russian movie 1612: Chronicles of the Time of Troubles was first shown in Poland on September 17, 2007, a clear reference to Russia's invasion at the beginning of the Second World War in 1939. Moreover, it is no coincidence that when the Polish movie 1920 Battle of Warsaw, was made in 2011, by Jerzy Hoffman, the same Polish actor who had played in the Russian movie, Michał Żebrowski, was now cast as the Polish Prime Minister. In addition, the (currently in power) right-wing Law and Justice party propounds the theory that Poles need to select from their history heroic and laudable moments, and use them as projections for their own deeds. To this end, the Polish-Bolshevik war of 1920, the Round Table talks of 1989 and the Smolensk air crash of 2010 all serve their purpose. ${ }^{2}$ Alongside these examples, however, the story of Poland's occupancy of the Muscovy throne also plays a prominent role. ${ }^{3}$

Interestingly, Polish and Russian historiographical explanations of this clash developed to a great extent independently from each other. In the period between the two world wars, we observe a mutual lack of interest between Bolshevik historians and Polish historians writing their country's history after having gained national independence. ${ }^{4}$ In the first years of the Polish People's Republic, an intense dialogue between Russian and Polish historians in rewriting Polish-Russian history took place, but no primacy was given to the Time of Troubles. Russian books containing the Soviet historiographical template about the Smuta were simply translated into Polish, and most Polish historians avoided analysing the Time of

Science Fund (FWF) under the grants M 1311-G 15 and V 360-G 22. I would like to thank the organizers and participants to the conference "Children and War: Reflecting on Wartime Childhood across the Centuries" (Mainz, 2015) for the invaluable comments they provided after my oral presentation. I would also like to thank my colleague Ulrich Hofmeister for his helpful remarks. I am grateful for the research assistance provided by Izabela Mrzygłód and Marcin Bogusz and for the proofreading offered by Mark Trafford.

1. Roman Svetlov, Druz'ia i vragi Rossii: Karmannyi slovar' [Friends and enemies of Russia: A pocket dictionary] (SPb.: Amfora, 2002), quoted in: Wacław Radziwinowicz, Gogol w czasach Google'a: korespondencje z Rosji 1998-2012 [Gogol in the Google era: Letters from Russia 1998-2012] (Warszawa: Agora, 2013) 143.

2. Mariusz Janicki, Wiesław Władyka, "Władcy historii [The Masters of History]," Polityka, 39 (2015): 24-27.

3. Hieronim Grala, "Wielka Smuta w pamięci historycznej Polaków [The Time of Troubles in Polish Collective Memory]," in Irina Adel'gejm, Viktoriia Mochalova, Nataliia Filatova and Ol'ga Cybenko, eds., Victor Chorev - Amicus Poloniae: $k$ 80-letiiu Viktora Aleksandrovicha Khoreva: mezhdunarodnaia konferenciia [Victor Chorev - Amicus Poloniae: on the occasion of Victor Aleksandrovic Chorev's 80 ${ }^{\text {th }}$ birthday: international conference] (M.: Institut slavianovedeniia, 2012), 35 .

4. Leonid Efremovich Gorizontov, "Metodokogicheskij perevorot v pol'skoj istoriografii rubezha 40-50-kh gg. i sovetskaia istoricheskaia nauka [The methodological revolution in Polish historiography at the turn of the 1950s and Soviet historiography]," in Alina BarszczewskaKrupa, W kręgu historii historiografii i polityki [In the circle of the history of historiography and politics] (Łódź: Wydawnictwo Uniwersytetu Łódzkiego, 1997), 108; Andrzej Grabski, Zarys historii historiografii polskiej [An outline of Polish historiography] (Poznań: Wydawnictwo Poznańskie, 2000), 169. 
Troubles and concerned themselves instead with archaeology and economics. ${ }^{5}$ Although some Polish historians started to write about the Smuta in books without a significant outreach from the 1960s onwards, the first history books after the Second World War analysing Polish-Russian relations during Sigismund III Vasa's reign on the basis of new archival research were only published after the collapse of communism.

However, over the course of Poland's short twentieth century (from when Poland reappeared on the map of Europe in 1918 until the collapse of communism), the Time of Troubles occupied an important place in secondary school history textbooks. Portrayed differently over time, the Time of Troubles functioned as a key tool to develop within Polish pupils a specific desired attitude towards the society in which they lived. School textbooks often became a more important means for the proliferation of narratives of the past than books published by professional historians, not least because the role of the Polish state in education grew significantly throughout the twentieth century. During the interwar period, the Polish state became one of the main organisers of schools and employers of teachers, next to the social and religious organisations that had previously dominated the field. The leading Polish interwar statesman Józef Piłsudski appeared more successful with his aims to bring education into uniformity than he managed with professional historiography. ${ }^{6}$ After the Second World War, state intervention in education grew into a monopoly controlled by the Communist Party. Since school textbooks were constantly being published, they are therefore incredibly relevant research objects that enable us to see how attitudes to the Time of Troubles changed over time.

In analysing how the historical events of the beginning of the seventeenth century were presented to secondary school students, and indicating the meaning students were supposed to infer from such presentations, particular attention is paid to those key elements in the narratives that changed drastically over time. To that purpose, I will discuss how authors began their narratives on the Time of Troubles, how heroes were depicted and their virtues glorified, and, finally, how the end of the Time of Troubles in 1612/1613, and later 1618, was recounted. The article identifies which historical messages were put to use, and how these messages changed, in educating new generations of citizens about their place and role in the world.

The collection I gathered for the analysis of the interwar period consists of eight school history textbooks, of which three were approved by the Ministry of Religious Faiths and Public Education (Ministerstwo Wyzwań Religijnych i Oświecenia Publicznego) as suitable materials for teaching in state schools. As the published versions of two of these could not be traced, I worked with the unpublished archived

5. Maciej Górny, The Nation Should Come First: Marxism and Historiography in East Central Europe (Frankfurt am Main: Peter Lang Edition, 2013), 60.

6. Grabski, Zarys historii, 173. 
versions. ${ }^{7}$ For the communist period, the school textbooks I chose were both intensively discussed within circles of historians and educators and widely used within schools: five textbooks for students and three books that teachers could use as didactic material. The analysis of Polish secondary school history textbooks is accompanied by an analysis of archived teaching programmes and related documents of the Polish Ministry of Education. By examining how contemporary professional historiographers described the Time of Troubles, I have been able to evaluate the extent to which historical knowledge made its way into the classroom over time.

\section{"The biggest rapprochement between Poland and Moscow"}

After Poland reappeared on the map of Europe as an independent state in 1918, the topic of education appeared on the agenda of its political representatives. The percentage of the national budget spent on education increased from $2 \%$ to $10 \%$ between 1921 and 1922, since education was seen as one of the most important starting points for state activity. ${ }^{8}$ Political representatives were optimistic now that Poles could decide for themselves how Polish history and the Polish language would be taught. Whereas before independence patriotism had meant fighting against the state, it would now refer to a citizen's consciousness about his rights and duties. State engagement in the rearing of children remained initially limited to the establishment and functioning of an Educational Commission (Komisja Oświatowa) in the Polish Parliament. As a result, much improvisation and pragmatism was required on the part of individual teachers and school textbook writers in defining teaching content. ${ }^{9}$

After Piłsudski's military overthrow of the government in 1926, leading to the Sanacja movement being in power until the outbreak of the Second World War, however, the discussion concerning the kind of role the Polish state should play in

7. Adam Szelągowski, Dzieje Polski w zarysie [A brief history of Poland] (Warszawa-Kraków: J. Czernecki, 1923); Wincenty Zakrzewski, Historia powszechna na klasy wyższe szkół średnich [General history for senior high school classes], vol. 3: Historia nowożytna [Modern History (Warszawa: Gebethner i Wolff [1923]); Czesław Nanke, Historia nowożytna. Podręcznik dla klas wyższych szkół średnich [Modern History: Textbook for senior high school classes] (Lwów-Warszawa: Książnica-Atlas, 1929); Tadeusz Bornholtz, Historia dla II klasy gimnazjów [History for 2nd gymnasium class] (Warszawa: Gebethner i Wolff, 1934); Jan Dąbrowski, Historia dla II klasy gimnazjów [History for 2nd gymnasium class] (Lwów: K.S. Jakubowski, 1934); Jadwiga Lechicka, Historia dla I klasy liceum [History for 1st high school class] (Lwów: Zakład Narodowy im. Ossolińskich, 1938). Archival materials: AAN (Archiwum Akt Nowych) MWRiOP (Ministerstwo Wyznań Religijnych i Oświecenia Publicznego), 209: Projekty podręczników. Historia dla klasy II gimnazjum [History for 2nd gymnasium class (draft version)], 1-244; AAN MWRiOP, 210: Projekty podręczników. Podręcznik do nauki historii na II klasę gimnazjalną, egzemplarz dla recenzenta [History Textbook for 2nd gymnasium class (review copy)] (1934), 1-250; AAN MWRiOP, 211: Projekty podręczników. Historia dla klasy II gimnazjalnej [History for 2nd gymnasium class (draft version)], 1-281.

8. Stephanie Zloch, Polnischer Nationalismus: Politik und Gesellschaft zwischen den beiden Weltkriegen (Köln-Weimar-Wien: Böhlau, 2010), 211, 243.

9. Zloch, Polnischer Nationalismus, 288. 
educating children intensified. ${ }^{10}$ Political representatives of the biggest opposition party after Piłsudski's coup, the Endecja (or National Democrats), were in favour of what they called a national upbringing (wychowanie narodowe). This idea had developed among the Polish elite during the nineteenth century and encompassed such virtues as patriotism, honesty and performance of deeds for the sake of the imagined fatherland. Since the concept was developed when Poland did not exist as a national state, it foresaw the state playing only a marginal role. ${ }^{11}$

The Sanacja movement in turn centralised education around the concept of state upbringing (wychowanie państwowe). According to its political ideology, the "good of the state" was to coincide with the "good of the individual." 12 To that purpose, the virtuous individual was to work in solidarity with his fellow countrymen for the sake of the state. He would need to be led by members of a newly created social elite, which did not share a privileged background - as had been the case before - but shared the Sanacja ideology. Schools became important instruments in the hands of the state enabling the training of such elite members. ${ }^{13}$

By the late 1920s, Sanacja ideology and a certain strand of thought in Polish pedagogy found common ground and strove to reform the educational landscape. Mainstream Polish pedagogy had moved away from positivistic models of practising education, towards foregrounding norms and values such as democracy and humanitarianism. ${ }^{14}$ Reforms introduced in 1932 required teachers to stimulate pupils to work together, so that the smarter children would help out their peers, and to reward students with certificates for both the demonstration of outstanding social attitudes and knowledge (especially within the domains of Polish language and history)..$^{15}$ Secondary school education was supposed to offer an intensified training in becoming proud of the Polish Fatherland ${ }^{16}$ National history courses were

10. Krzysztof Jakubiak, Wychowanie państwowe jako ideologia wychowawcza sanacji: kształtowanie $i$ upowszechnianie $w$ periodycznych wydawnictwach społeczno-kulturalnych i pedagogicznych [State education as the educational ideology of sanation: shaping and dissemination in periodic socio-cultural and educational publications] (Bydgoszcz: Wyższa Szkoła Pedagogiczna, 1994), 44-45.

11. Barbara Jakubowska, Przeobrażenia szkolnej edukacji historycznej w Polsce w latach 1944-1956 [The transformation of school historical education in Poland in the years 1944-1956] (Warszawa: Centralny Ośrodek Metodyczny Studiów Nauk Politycznych, 1986), 44-45.

12. Stanisław Seweryn, "Zagadnienia wychowania państwowego [Issues of state education]," Sprawy szkolne, 7 (1932), no. 1-2: 9.

13. Józef Miąso, ed., Historia wychowania. Wiek XX [History of education. XX century], vol. 1 (Warszawa: Państwowe Wydawnictwo Naukowe, 1984), 81.

14. Danuta Drynda, "Niektóre koncepcje pedagogiki naukowej w Polsce międzywojennej [Some concepts of scientific pedagogy in interwar Poland]," in Danuta Drynda, ed., Studia z historii polskiej pedagogiki: Koncepcje pedagogiczne w Drugiej Rzeczypospolitej [Studies in the history of Polish pedagogy. Pedagogical concepts in the Second Polish Republic] (Katowice: Uniwersytet Śląski, 1993), 27.

15. Jakubiak, Wychowanie państwowe, 54; Jakubowska, Przeobrażenia szkolnej edukacji historycznej, 24.

16. Bogdan Suchodolski, Liceum Ogólnokształcące [The High School] (Lwów: Książnica-Atlas, 1938), 14. 
intended to instil in Polish secondary school pupils a positive emotional attachment to their state and a feeling of readiness to function as citizens. ${ }^{17}$ Such aims required new school history textbooks. Although efforts were initially concentrated on primary school textbooks, by 1937 history teaching in secondary schools followed a teaching programme operating according to similar criteria. It would be the Polish Ministry of Religious Faiths and Public Education that decided which new history textbooks were suitable for use in state secondary schools. ${ }^{18}$ Although private school teachers were allowed to use other history textbooks, most implemented the state guidelines..$^{19}$ In the school year 1938-1939, 36,700 pupils distributed over 668 high schools (or lyceums), of which 290 were state schools and 378 were private, learned history with the help of the approved textbooks. ${ }^{20}$

The Ministerial teaching programme of 1937 explained the need for the teaching of history as follows ${ }^{21}$ :

[Pupils would gain an] understanding of factors influencing the development and progress of nations and states, in particular of Poland, making [them] conscious of the role of the individual in the process of action and, in relation to that, preparing them for a responsible and creative contribution to, and participation in, the life of their nation and state. ${ }^{22}$

Providing pupils with documented reasons for taking pride in their own past places the accent on certain historical episodes, while pushing others to the sidelines. In Polish school history textbooks of the interwar years, the Jagiellonian Empire's expansion and the harmonious cohabitation of different nations in the PolishLithuanian Commonwealth of the sixteenth century are described at great length, as these elements were considered examples of what the Polish interwar state aspired to emulate. ${ }^{23}$

\section{Miąso, ed., Historia wychowania, 67.}

18. Program nauki w liceum ogólnokształcącym: Historia. Wydział matematyczno-fizyczny i przyrodniczy (projekt): AAN MWRiOP, 193, 129. For prepatory work on the teaching program see Ministerstwo Wyzwań Religijnych i Oświecenia Publicznego, Wytyczne dla autorów programów szkół ogólnokształcących: szkoła powszechna: gimnazjum [Guidelines for authors in high schools: public school: gymnasium] (Warszawa 1932).

19. Jakubiak, Wychowanie państwowe, 40.

20. Miąso, ed., Historia wychowania, 82.

21. In interwar Poland, three types of lyceums existed: classical, humanistic, and those specialising in exact sciences (mathematics, physics and biology). Only the teaching programme of the last specialisation survived the devastation of the Second World War. Although this type featured the least amount of hours of history teaching, the programme can still give an indication of the Ministry's aims regarding history teaching. See Miąso, ed., Historia wychowania, 63.

22. See AAN MWRiOP, 193, 129.

23. Marian Henryk Serejski, ed., Historycy o historii: 1918-1939 [Historians on History], vol. 2 (Warszawa: Państwowe Wydawnictwo Naukowe, 1966, 23; Jakubowska, Przeobrażenia szkolnej edukacji historycznej, 35. 
Interwar depictions of the Polish-Lithuanian Commonwealth paid tribute to the first Polish historian who offered a scholarly synthesis of Polish history, Joachim Lelewel (1786-1861). According to him, the example of the Commonwealth's community of noblemen bonded by the practice of civil freedom, rather than religion or ethnicity, should form the foundation for a future democratic Polish state. ${ }^{24}$ He put great emphasis on the importance of altruism among noblemen, since acting only in favour of one's own interests could ruin the community. ${ }^{25}$ That is why he negatively evaluated both the initiative of noblemen to intervene in Russia's affairs without the permission of Sigismund III Vasa in 1605-06, and the decision of Sigismund III Vasa to march to Moscow in 1612 acting against the convictions of a majority of noblemen. ${ }^{26}$ Interwar historiography had a mixed view of the Commonwealth, with some regarding it as having been a phenomenon of voluntary cooperation between various nations, and others as the product of Polish political national expansion. ${ }^{27}$ In interwar school textbooks, however, a more straightforward appreciation of the latter position can be found.

Rather than detailing the deeds of the Polish-Lithuanian Commonwealth kings, textbooks authors focused their efforts on describing the various noblemen who had loyally served their Fatherland. Stanisław Żółkiewski in particular was believed to have embodied the virtues of an exemplary citizen, because he had conquered Moscow in 1610 for his king and had prepared a union between the Polish-Lithuanian Commonwealth and the Muscovite Empire. ${ }^{28}$ A good example of such a presentation can be found in the Polish interwar history schoolbook Historia dla klasy II gimnazjów written by Tadeusz Bornholtz in 1934 and approved by the Ministry of Religious Faiths and Public Education in 1937 as a textbook meeting the requirements of its new history teaching programme for secondary schools. On one of the first pages, the book contains a list of 15 important dates pupils needed to remember from the "first historical emergence of Poland" in 963 until the end of the seventeenth century, when in 1683 the Polish king "Sobieski saved Vienna." Next to 1683 , the list contains one other date related to the seventeenth century. In 1610, it was written, the Battle of Klushino had been "won." ${ }^{29}$ That the 1610 victory was followed by a defeat in 1612 having more important long-term consequences pupils did not need to learn by heart. As such, the list clearly demonstrates how victories constituted the key elements of a positive reading of history for Polish pupils. The

24. John D. Stanley, “Joachim Lelewel (1786-1861)," in Peter Brock, John D. Stanley and Piotr J. Wróbel, eds., Nation and History: Polish Historians from the Enlightenment to the Second World War (Toronto: University of Toronto Press; 2006), 67, 72.

25. Ibid., "Joachim Lelewel," 62.

26. Joachim Lelewel, Dzieje Polski [A history of Poland] (Lwów: Drukarnia Zakładu Narodowego im. Ossolińskich, 1848), 159, 160.

27. Grabski, Zarys historii, 177-179; Ludwik Kolankowski, Polska Jagiellonów: dzieje polityczne [Jagiellonian Poland: political history] (Lwów: Gubrynowicz i Syn, 1936), 25.

28. Jakubowska, Przeobrażenia szkolnej edukacji historycznej, 32.

29. Bornholtz, Historia dla II klasy gimnazjów, 179. 
fact that other milestones of seventeenth century history, such as the Pereiaslav agreement of 1654 and the Andrusovo truce of 1667, are not included in the list, indicates they were considered less important for native history. ${ }^{30}$

Let us now have a closer look at the depiction of the Time of Troubles in the most important school history textbooks from the interwar period. One school textbook of the late 1930s, recounting the march to Smolensk and Moscow in 1609 and the Battle of Klushino in 1610, along with a tendentiously abridged aftermath, is entitled "Victory over Moscow," which gives us a good idea of the kind of upbeat zealous patriotism served up to Polish pupils in the interwar period. ${ }^{31}$ An even more nationalistically inclined example of periodisation can be found in the Jan Dąbrowski schoolbook, which begins its description of the Time of Troubles as early as 1598 since that enabled the authors to credit the Polish-Lithuanian Commonwealth for the weakness of the Muscovite Empire:

Moscow had not been able to recover from the blow inflicted by Batory, while the death of Ivan the Terrible's son in 1598 had thrown it into anarchy and disarray. ${ }^{32}$

Earlier schoolbooks had expressed a much more nuanced and diverse perspective. Although Wincenty Zakrzewski, for example, was a forerunner of positive historiographical interpretation and endeavoured to write a history free of political doctrines, he was nevertheless influenced by the Cracow historiographic school of the nineteenth century that considered Poles responsible for their own failures throughout history because they had chosen weak leaders and could not control anarchy. ${ }^{33}$ Zakrzewski started his story of the Time of Troubles with what he called an "anarchistic" nobility opposing King Sigismund III Vasa in 1606. Just like the most renowned representative of the Cracow historiographical school of thinking from the nineteenth century, Szujski, he was in favour of a strong central power. ${ }^{34}$

The narrative of the Time of Troubles in Polish interwar history schoolbooks revolves around the figure of Hetman Stanisław Żółkiewski, who was to function as the embodiment of civil virtues for Polish pupils. According to Jan Dąbrowski, the victory in Klushino in 1610 "belongs to the most fantastic actions of Polish cavalry and is at the same time an example of the great talent of Źółkiewski as

30. Górny, The Nation Should Come, 126.

31. AAN MWRiOP, 211, 190-192.

32. Dąbrowski, Historia dla II klasy gimnazjów, 194.

33. Serejski, ed., Historycy o historii, 30; Górny, The Nation Should Come First, 212.

34.Zakrzewski, Historia powszechna na klasy wyższe szkół średnich, 73; Józef Szujski, Historyi polskiej treściwie opowiedzianej ksiąg dwanaście [A 12-Volume History of Poland succinctly narrated] (Poznań: Wydawnictwo Poznańskiego Towarzystwa Przyjaciół Nauk, 2005), 259. 
a leader." ${ }^{35}$ Tadeusz Bornholtz even accompanied his four-and-a-half-page narrative of the Time of Troubles with a half-page illustration and the following caption underneath:

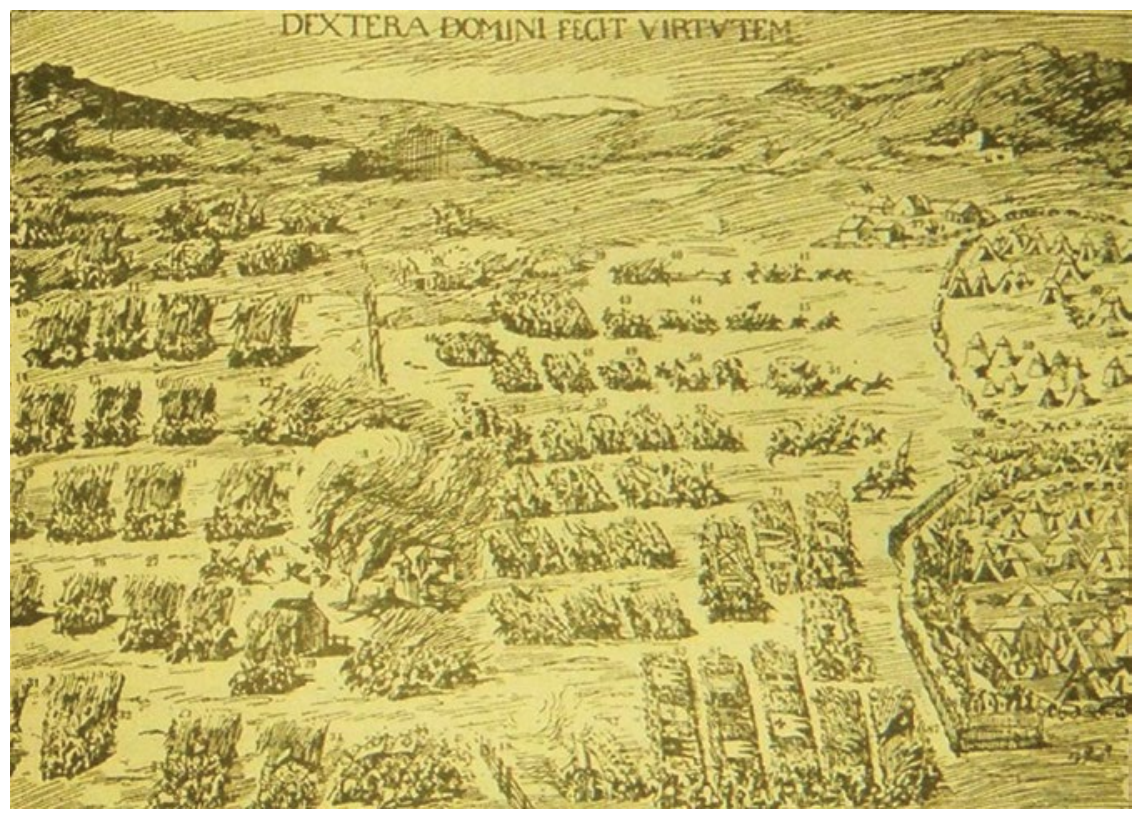

[Figure: The Victory in Klushino in the schoolbook of Tadeusz Bornholtz, page 179.]

On the left hand side is the Polish cavalry with lances; one of the divisions is preparing to attack. Three other divisions are already on the attack. In the centre is a burning village, to the left of it Żółkiewski is on his horse, and behind him two knights (with a small pennant). To the right of the fences we see the ranks of the Muscovite cavalry, a few of whom are attacking the Polish cavalry. At the top of the painting, to the right of the Muscovite army an infantry is situated opposite the Polish infantry. On the right side are two Muscovite camps, one surrounded by a chain of vehicles, the other by a palisade. There are two cannons between the camps. ${ }^{36}$

King Sigismund III Vasa, on the contrary, is depicted in mainly pejorative terms. Jan Dąbrowski writes:

Sigismund III was not characterised by either military talent or a knightly temperament, which the nobility had liked so much in Batory. However, he did manage to reach his personal goals thanks to huge persistence and stubbornness, first and foremost in acquiring the Swedish crown. ${ }^{37}$

35. Dąbrowski, Historia dla II klasy gimnazjów, 194. For a similar narration see Adam Szelągowski, Dzieje Polski w zarysie [A brief history of Poland] (Warszawa-Kraków: J. Czernecki, 1923), 150.

36. Bornholtz, Historia dla II klasy gimnazjów, 179.

37. Dąbrowski, Historia dla II klasy gimnazjów, 191. 
Other authors also presented King Sigismund III as being stubborn. When the Siege of Smolensk in 1609 lasted longer than had been anticipated, Hetman Żółkiewski encouraged the king to move on to Moscow. The king's refusal to listen to such a plan is recounted by both Tadeusz Bornholtz and Czesław Nanke. ${ }^{38}$

At a popular level, interwar history writing about Hetman Żółkiewski and King Sigismund III fell into line with the narrative offered in Polish history schoolbooks, with the memoirs of Żółkiewski, for example, first being printed in $1920 .{ }^{39}$ Interwar professional historiography, however, evaluated these historical actors differently. Wacław Sobieski, for example, concluded that both King Sigismund III and Zółkiewski had nursed unrealistic imperialistic plans. ${ }^{40}$ By contrast, in the first university textbook on Polish history, published in 1936, Władysław Konopczyński called both Żółkiewski’s victory at Klushino and Sigismund’s victory at Smolensk a year later "triumphs." 41

After Żółkiewski’s victory at Klushino, Polish secondary school textbooks from the interwar period tell us that he negotiated a form of cooperation similar to the one practiced in the Polish-Lithuanian Commonwealth with the Muscovite boyars. The proposed union would offer freedom for the nobility and tolerance between people of different confessions under the lead of King Sigismund III Vasa's son, Ladislaus IV, who was to convert from Catholicism to Orthodoxy. Czesław Nanke praises this action of Żółkiewski as:

the biggest rapprochement between Poland and Moscow; it appeared that Batory's great plan of linking both states into a union was close to realisation, and this was thanks to the work and wise conduct of Żółkiewski. ${ }^{42}$

With the aim of educating a new generation of citizens, the Sanacja regime employed this episode of early seventeenth century history to demonstrate the importance of voluntary co-operation between people of different backgrounds and tolerance for minorities. ${ }^{43}$ For instance, the anonymous author of an unpublished

38. Bornholtz, Historia dla II klasy gimnazjów, 178; Nanke, Historia nowożytna, 138.

39. Stanisław Żółkiewski, Początek i progres wojny moskiewskiej [The start and progression of the Polish-Moscovite War] (Kraków: Krakowska Spółka Wydawnicza, 1920); reprinted in 2010.

40. Wacław Sobieski, Żółkiewski na Kremlu [Zółkiewski in the Kremlin] (Warszawa: Gebethner i Wolff, 1920), 210.

41. Władysław Konopczyński, Dzieje Polski nowożytnej [A history of modern Poland] (Warszawa-Kraków: Gebethner i Wolff, 1936), 230, 233. Władysław Konopczyński was not only one of the most productive historians from the interwar years, he was also a representative in the Polish Parliament for the National Democrats. It is therefore not surprising that his university textbook is less nationalistic than the secondary school handbooks approved by the Ministry of Religious Faiths and Public Education. See Jerzy Maternicki, "Wstęp," [Introduction] in Władysław Konopczyński, Dzieje Polski nowożytnej [A history of modern Poland] (Warszawa: Pax, 1996), 49-50.

42. Nanke, Historia nowożytna, 139.

43. Górny, The Nation Should Come First, 214; Serejski, ed., Historycy o historii, 23. 
school textbook approved by the Ministry of Religious Faiths and Public Education was careful to stress that: "Żółkiewski guaranteed that Poles did not misuse their position to the detriment of the local people." 44 At the same time, King Sigismund is portrayed as an egoist who wanted to baptise Muscovites into Catholicism and who demanded the throne for himself. ${ }^{45}$ Whereas school textbook authors are unambiguously positive about the agreement, historians such as Oskar Halecki did not see the possibility of a modus vivendi with Russia because of religious differences, and therefore considered the agreement unrealistic. ${ }^{46}$

Let us now have a look at the way Polish interwar school textbooks described the historical period between the Battle of Klushino in 1610 and the coronation of Mikhail Romanov in 1613. The fact that some authors of 1920 textbooks, such as Jan Dąbrowski, do not mention the date 1612, even though this was the year when Polish aspirations to the Moscow throne in particular, and expansion towards the East in general, were stymied, is an example of how interwar Polish school textbooks tried to avoid any mention of political and military failures ${ }^{47}$ Other authors, such as Szelągowski, for example, mention these events briefly, but refrain from the kind of emotional engagement that characterises their descriptions of the Battle at Klushino in 1610:

From that moment, when the Poles lost the capital of tsars and the Kremlin castle (at the end of the year 1612) and Moscow elected the Romanov dynasty to the throne (February 1613)... ${ }^{48}$

More nationalistic schoolbooks written in the 1930s tell Polish pupils that the Kremlin castle was lost in 1612 because King Sigismund III left his brave fighters alone in hunger and realised too late he should have allowed his son Ladislaus to secure authority in Moscow. ${ }^{49}$ Notwithstanding the defeat, many Polish interwar history schoolbooks end their narratives of the Time of Troubles positively by emphasizing the enduring influence Polish civilisation had brought about. ${ }^{50}$ Whereas the provisional Truce of Deulino, signed in 1618 in order to put an official end to the nine-year war between the Polish-Lithuanian Commonwealth and the

44. AAN MWRiOP, 210, 181. See also AAN MWRiOP, 211, 191.

45. Nanke, Historia nowożytna, 139; AAN MWRiOP, 211, 192.

46. Oskar Halecki, La Pologne de 963 à 1914: essai de synthèse historique (P.: Alcan, 1933), 184. See also Janusz Cisek, Oskar Halecki: historyk, szermierz wolności [Oskar Halecki: historian, swordsman of freedom] (Warszawa: Instytut Pamięci Narodowej, 2009), 35.

47. Dąbrowski, Historia dla II klasy gimnazjów, 197-198; Jakubowska, Przeobrażenia szkolnej edukacji historycznej, 27.

48. Szelągowski, Dzieje Polski w zarysie, 151.

49. Nanke, Historia nowożytna, 139; Bornholtz, Historia dla II klasy gimnazjów, 181.

50. Serejski, ed., Historycy o historii, 24. 
Muscovite Empire ${ }^{51}$ receives only minimal attention, Podręcznik do nauki historii na II klasę gimnazjalną (draft version), for example, concludes:

While Żółkiewski’s expedition to the Kremlin did not lead to either a union or Poland's capture of Moscow, it did ultimately confirm the Commonwealth's advantage over its frightening eastern neighbour and contributed in no small measure to the strengthening of Polish cultural influence on Moscow. ${ }^{52}$

Such a presentation can be explained by the fact that historians had developed a greater interest in cultural and economic history in the interwar years. At Vilnius University, for example, Research Groups for Economic and Cultural History in 1935 were established. ${ }^{53}$ While this emerging interest in culture found its way into the narratives of the Time of Troubles in interwar Polish school textbooks, economic aspects are oddly left out. This is despite the fact that Polish historians in the interwar years had revealed that an important reason for King Sigismund's expedition in 1612 being late had been his inability to gather enough money for his military campaign.

In 1938, Poland was preparing itself for the war that would break out a year later. Pupils, it was believed, needed to be educated accordingly. A mere year after the teaching programme had been implemented, it was already changed into a "political preparation for fulfilling the duties of an armed nation by means of the powerful weapon that the nation represents." ${ }^{54}$ Putting the national-military element at the fore, the schoolbook of Jadwiga Lechicka offers the Time of Troubles under the heading: "The organisation of Polish national defence in the seventeenth century." Unlike the interwar school textbooks earlier discussed in this article, here the heroic depiction of Stanisław Żółkiewski continues until he is murdered in 1620 during the Polish-Lithuanian Commonwealth's retreat after the Battle of Cecora against the Turks, as such a presentation enables the author to cite Żółkiewski's reflections about his future engagement in what would become his last battle:

However, should it be necessary for me to die [...] let my coffin be covered with crimson as a symbol of blood shed for the Republic, not to further my own glory, but for other motives; it should serve as a wake-up call for others to practice virtue and respect for their Fatherland. ${ }^{56}$

51. The Polish-Lithuanian Commonwealth enjoyed territorial gains: the city of Smolensk, the Chernigov regions and a big part of Severia, but abandoned its expansionist aspirations in the East. See Chester S.L. Dunning, Russia's First Civil War: The Time of Troubles and the Founding of the Romanov Dynasty (University Park, Pennsylvania: Pennsylvania State University Press, 2001), 457.

52. AAN MWRiOP, 210, 181-182.

53. Górny, The Nation Should Come First, 214; Serejski, ed., Historycy o historii, 276.

54. Józef Pieter, "Wychowanie obywatelsko-państwowe [Civic Upbringing]," Miesięcznik Pedagogiczny, no. 5 (May 1938): 129.

55. Jadwiga Lechicka, Historia dla I klasy liceum [History for 1st high school class] (Lwów: Zakład Narodowy im. Ossolińskich, 1938), 279.

56. Lechicka, Historia dla I klasy liceum, 287. For more information on the battle of Cecora, see Marian Kukiel, Zarys historii wojskowości [A brief military history] (Kraków: Krakowska 


\section{"For the ideological content of schools, the most important thing is a history textbook"}

As early as August 1945, an archival document of the Propaganda Department of the Polish Workers' Party (Polska Partia Robotnicza or PPR), which together with its allies from other political parties controlled seventeen of the twenty-one ministries, states: "For the ideological content of schools, the most important thing is a history textbook." ${ }^{57}$ Six weeks after falsified elections had resulted in a majority for the Democratic Block consisting of pro-communist politicians, the Educational-Cultural Commission (Komisja Oświatowo-Kulturalna) was established. It introduced far-reaching changes to the educational landscape, such as the elimination of private schools, the obligatory ideological training of teachers, a state monopoly over the publication of school textbooks and the limitation of humanistic secondary school education..$^{58}$ In this type of school, 1,2 million pupils were trained in 1945, 2,4 million in 1960 and 3,7 million in 1980. Whereas $65 \%$ of youngsters did not attend secondary schools in 1946, in 1960 that number had dropped to $35 \%$, and in 1980 it was below 5\%..$^{59}$ Education under communism clearly served another aim than it had done in the interwar years. Instead of rearing a small group of selected new elite members, the aim was now to create an egalitarian society by educating the masses according to a strictly controlled historical interpretation of the past.

A new Communist Party directive in 1949 ordered a group of historians to write textbooks for primary and secondary school children under the direction of Żanna Kormanowa ${ }^{60}$ The aspiration of implementing Soviet frames of historiographical thinking cannot be formulated better than by Kormonowa herself:

Militant, international and partisan, Soviet historiography rushes to help the people's democracy countries, building socialism according to the example of the USSR, in the creation of a Marxist-Leninist historiography. ${ }^{61}$

In the 1980s, the Polish historian Barbara Jakubowska compared the aims of history teaching in the programmes of the Polish Ministry of Education over time. Whereas

Spółka Wydawnicza, 1929), 74.

57. AAN PPR, 295/XVII/50, 16.

58. Krzysztof Kosiński, Oficjalne i prywatne życie młodzieży w czasach PRL [Official and private lives of youth in the Polish People's Republic] (Warszawa: Rosner \& Wspólnicy, 2006), 12-15.

59. Ibid., 8.

60. Rafał Stobiecki, Historiografia PRL. Ani dobra, ani mądra, ani piękna..., ale skomplikowana. Studia i szkice [Historiography in the Polish People's Republic. Neither good nor wise, nor beautiful... but complicated. Studies and drafts] (Warszawa: Wydawnictwo Trio, 2007), 262.

61. Żanna Kormanowa, "O radzieckiej nauce historycznej [On Soviet historical science]," Kwartalnik Historyczny, 58 (1950/51), 1: 81. 
in 1933/1934, citizens were to identify with the successes of the Polish state, in 1947 the emphasis was placed on an understanding of economic processes and their role within society. In the 1950 programme history teaching had evolved even further: now the working class was glorified and the invented class enemy was negatively depicted $^{62}$ More specifically, during the Stalinist period, Polish historiography presented the expansionist ideas of the nobility in the Polish-Lithuanian Commonwealth to the east during the 16th and seventeenth century as a betrayal of Slavic interests, because they failed to defend their Slavic brothers in the west, the Polabian Slavs, against a German invasion, and their activities in the east causing aggression against other Slavs. ${ }^{63}$ The Time of Troubles in particular was considered the nadir of this expansion and presented as a fight between "obscurantism and progress." ${ }^{4}$

The communist regime needed new school textbooks depicting the popular masses as prominent historical actors. Due to the persistent lack of clear criteria over the evaluation of interwar Polish historiography and the fact that primary school textbooks took priority, it wasn't until the beginning of the 1950s that the first history textbooks for secondary school pupils were printed. ${ }^{65}$

The textbook of the Russian author Aleksei Vladimirovich Efimov was translated from Russian into Polish and was recommended in the teaching programme of the Ministry of Education in 1954/1955 as a new and useful school textbook, as was the translated textbook of Anna Mikhailovna Pankratova, a Russian historian and pedagogue specialised in the history of the Russian workers' movement. ${ }^{66}$ Not surprisingly, her description of the Time of Troubles carries the title: "Peasant War and Struggle with Polish and Swedish intervention in the Russian state at the beginning of the seventeenth century." ${ }^{67}$ In addition, Polish and Russian historians

62. Jakubowska, Przeobrażenia szkolnej edukacji historycznej, 293, 309.

63. Błachowska, "Rosja w historiografii polskiej," in Andrzej Wierzbicki, ed., Klio polska: studia i materiały z dziejów historiografii polskiej po II wojnie światowej [Polish Clio: studies and sources from a history of Polish historiography after the Second World War] (Warszawa : “Neriton"-Instytut Historii PAN, 2004), 157.

64. Ibid., 159.

65. See Anna Mikhailovna Pankratova, ed., Historia ZSRR [A history of the Soviet Union], vol. 1 (Warszawa: Państwowe Zakłady Wydawnictw Szkolnych, 1954). A Polish translation of this history book was recommended by the Ministry of Education as a useful reference book for history teachers (Błachowska, "Rosja w historiografii polskiej," 166). See also Stanisław Arnold, eds., Historia Polski [A history of Poland] (Warszawa: Państwowe Zakłady Wydawnictw Szkolnych, 1954), Aleksandr Efimov, Historia nowożytna [Modern History] (Warszawa: Państwowe Zakłady Wydawnictw Szkolnych, 1954).

66. Ministerstwo Oświaty, Instrukcja programowa i podręcznikowa dla 11-letnich szkół ogólnokształcących na rok szkolny 1954/1955. Historia. Klasy VIII-XI [Manual of programs and textbooks for 11-year-old general education schools for the year of 1954-1955, History, Class VIII-XI] (Warszawa: Państwowe Zakłady Wydawnictw Szkolnych, 1954), 65. The work on a university handbook of history and the reception of first published draft versions illustrate the political transformations of Stalinist Poland more in detail see Gorny, The Nation Should Come First, 60-66; Henryk Łowmiański, ed., Historia Polski [History of Poland], vol. 1, part 2 (Warszawa: Państwowe Wydawnictwo Naukowe, 1957), 4.

67. Anna Mikhailovna Pankratova, Konstantin Vasil'evich Bazilevich and others, eds., Istoriia SSSR: uchebnik dlia 8 klassa srednei shkoly [History of the USSR: Textbook for the $8^{\text {th }}$ grade 
together rewrote previous Polish-Russian encounters, such as the importance of the involvement of Poles in the Bolshevik revolution for the establishment of Polish independence, but not the Time of Troubles. ${ }^{68}$ The discussion that took place in 1955 between Russian and Polish historians about the draft of the second volume of the new Soviet standard work about Polish history gives an insight into the reason why Polish historians accepted the Soviet narrative of the Time of Troubles. Such a depiction of the Smuta happened to function as a tradeoff, which Polish historians were happy to accept if, as they proposed, the reactionary forces against the Russian Tsar during the nineteenth century would not be limited to the Polish nobility. Polish historians told their Soviet counterparts that the struggle for social liberation could not be separated from the struggle for independence. They did not accept the juxtaposition of the Polish nobility with the Polish masses and therefore required that $19^{\text {th }}$ century reactionary forces be given a broader social Polish basis in the volume. ${ }^{69}$ Although their suggestion was not accepted and incorporated into the Soviet book, it was realised a little later in the biggest Polish history book about Poland written in the late $1950 \mathrm{~s}^{70}$

In order to be able to introduce the subject of class struggle and present it as the cause of historical progress, the Polish school history textbooks from the Stalinist time offer an earlier periodisation of the Time of Troubles than the interwar ones. The textbook of Stanisław Arnold from 1954, for example, introduced farmers as historical actors who rebelled because they felt suppressed by Boris Godunov. The author continued: "Muscovite boyars wanted to make use of the unrest in order to enthrone Godunov, as did Polish magnates from the east in order to expand their territory." ${ }^{71}$ Because the farmers expected to be liberated from the yoke of despotism, they were disappointed when "Poles ran rampant in the capital of tsars." ${ }^{72}$ Although such a depiction was identical to the Soviet narrative on the Time of Troubles, it held tropes in common with the history writing of Michał Bobrzyński (1849-1935). A late disciple of the Cracow school, he identified the subjugation of the peasantry under nobles' jurisdiction (as had been the case during the period of the elective kings) as the reason for the state's inability to improve their situation. ${ }^{73} \mathrm{He}$ shared

in secondary school] (M.: Gos. Uchebno-pedagogicheskoe izdatel'stvo Ministerstva Prosvesheniia RSFSR, 1947), 154.

68. Błachowska, "Rosja w historiografii polskiej," 150.

69. Zbigniew Romek, "Polsko-radzieckie dyskusje o Istorii Polszi w trech tomach w latach 1950-1959," [Polish-Soviet discussions about Polish history in three volumes in the years 1950-1959] in Andrzej Wierzbicki, ed., Klio polska: studia i materiały z dziejów historiografii polskiej po II wojnie światowej [Polish Clio: studies and sources from the history of Polish historiography after the Second World War] (Warszawa: "Neriton"-Instytut Historii PAN, 2004), 185.

70. Łowmiański, ed., Historia Polski, vol. 1, part 2, 47-49.

71. Arnold, eds., Historia Polski, 74. See also Górny, The Nation Should Come First, 59.

72. Arnold, eds., Historia Polski, 75.

73. Philip Pajakowski, "History, the peasantry, and the Polish nation in the thought of Michal Bobrzyński," Nationalities Papers, 26 (1998), 2: 255-257. 
the Soviet belief that the Polish nobility should be presented as having been responsible for the eventual decline of the Commonwealth, due to their suppression of the peasants and unrealistic expansionist ideas. ${ }^{74}$

Another difference between interwar narratives on the Time of Troubles and those presented in secondary school textbooks during the Stalinist era can be found in the depiction of heroes. The main hero in the newer school history textbooks was now Ivan Bolotnikov, the leader of the uprising in 1606-1607 against Tsar Vasili Shuisky (1606-1610). Stanisław Arnold summed up the various social groups who were said to have supported Bolotnikov as follows: "peasants, Cossacks, lower strata of society, lower nobility," and only briefly mentioned Bolotnikov's defeat in the Siege of Moscow. ${ }^{75}$

School textbooks from the Stalinist era often ignore the figure of Stanisław Żołkiewski ${ }^{76}$ or reduce their description of the Battle of Klushino (1610) to the bare minimum:

the King sent part of his army under the command of Hetman Żółkiewski, who vanquished Shuisky's army at Klushino. ${ }^{77}$

Such a depiction is still more nationalistic than the one that can be read in translated Soviet history books from the time, in which the Muscovites lost the battle due to their treacherous "Swedish" and "German" allies switching sides. ${ }^{78}$ In addition, the end of the Time of Troubles is now narrated as a triumph for the supposed first Russian national army, supported by peasants, noblemen, the gentry and Cossacks, all fighting against Polish invaders under the command of Kuzma Minin and Dmitry Pozharsky: ${ }^{79}$

The fate of the Polish forces in the Kremlin was already decided: soon hungry Poles needed to surrender to the national army of Pozharsky [...] The national army also repulsed Sigismund III who was approaching Moscow with his new army in order to put Prince Ladislaus onto the tsarist throne..$^{80}$

The emphasis is clear: the Russian nation had won.

Despite the imposition of Soviet narratives onto Poland's past and communist control of schooling, history writing on the Time of Troubles continued to

74. Michał Bobrzyński, Dzieje Polski w zarysie [A brief history of Poland], vol. 2 (Warszawa: Gebethner i Wolff, 1927), 142

75. Arnold, eds., Historia Polski, 76; Dunning, Russia's First Civil War, 264, 268) See also Pankratova, ed., Historia ZSRR, 190.

76. Jakubowska, Przeobrażenia szkolnej edukacji historycznej, 297.

77. Arnold, eds., Historia Polski, 77.

78. Pankratova, ed., Historia ZSRR, 195.

79. Ibid., 197.

80. Arnold, eds., Historia Polski, 78. 
be characterised by fluctuating compromises between pre-war Polish schools of thought and Soviet concepts throughout the whole communist era. ${ }^{81}$ Even in the Polish school history textbooks of the Stalinist period we find traces of the interwar idea of tolerance represented by the Polish-Lithuanian Commonwealth, although this virtue is no longer embodied in the person of Stanisław Żółkiewski but presented impersonally: "the power of the future tsar was to be limited in favour of a council of boyars." 82 Interwar Polish historiography also lived on in the publications of Polish migrants in the Atlantic World. Oskar Halecki's popular history book pointed to Żółkiewski's feelings of duty to "defend the lawful sovereign". ${ }^{83}$ There was also the influential twentieth century Polish historian Witold Kula's habilitation thesis Wstęp metodyczny do badań nad rozwojem społeczno-gospodarczym Polski W XVI-XVIII wieku (1947) on the subject of Polish economic and social development in the early modern period.$^{84}$ Kula criticised early postwar Polish historiography for having produced "a flood of rubbish", as opposed to the burgeoning influence of the Annales school as a methodology researching long-term socio-economic evolutions in Polish history. Although his habilitation thesis remained unpublished, Witold Kula deeply influenced postwar Polish historiographical thinking. ${ }^{85}$

It is difficult to deduce precisely how pupils thought about the way they learned about the Time of Troubles. Research on the attitudes of the young in the Polish People's Republic indicates that in the years 1945-1948, when secondary schools were visited by children who had started their school career in the interwar years, many experienced the rewriting as betrayal. Their later colleagues, who learned about the Time of Troubles in 1949-1951 from school textbooks translated from Russian, are said to have been much more ideological than those from the time periods before and after. Many were grounded in communist ideology and enthusiastic due to the possibilities of social advance the regime offered. Among a later generation of 1952-1955, more youngsters were making a clear divide between what was written in the textbooks and what they were told in the private, family world. ${ }^{86}$

Following the softening of communism in Poland after the 1956 protests, an educational reform proposed bringing humanistic topics closer to pupils by

81. Górny, The Nation Should Come First, 260.

82. Arnold, eds., Historia Polski, 77.

83. Oskar Halecki, Historia Polski [A history of Poland] (Londyn: Veritas 1958), 137.

84. Witold Kula, Rozwój gospodarczy Polski XVI-XVIII wiek: Wstęp metodyczny [The economic development of Poland from the 16th to the 18th century: Metodological introduction], ed. Jacek Kochanowicz, (Warszawa: Wydawnictwo Naukowe PWN, 1993).

85. Górny, The Nation Should Come First, 60.

86. Hanna Świda-Ziemba, Młodzież PRL: Portrety pokoleń w kontekście historii [Youth of the Polish People's Republic: Portraits of the generations in a historical context] (Kraków: Wydawnictwo Literackie, 2010), 573 and further. 
introducing them to the traditions of their nation. ${ }^{87}$ The aim of history teaching in the learning programme of 1964-1965, for example, reads:

to incite love for the Fatherland and feelings of pride towards progressive and revolutionary traditions and the Polish nation's contemporary achievements in building socialism. ${ }^{88}$

This change in narrative can easily be detected in the presentation of the Time of Troubles in two editions of the school textbook of Helena Michnik, the first one dating from 1956 and the second from 1966. Although the narrative of both is characterised by a focus on class struggle and the first Russian national movement, a shift in the depiction of heroes is noticeable over time. Hetman Żółkiewski makes his entry again in the 1956 edition, but his depiction is short and neutral:

At Klushino the Polish army under the command of Hetman Żółkiewski routed the army of Shuisky. The victory at Klushino opened the way to Moscow for the Polish army under his lead. ${ }^{89}$

Ivan Bolotnikov, and especially the masses he coordinated in resisting the Polish noblemen, receives less attention than in Polish school history textbooks from the Stalinist era..$^{90}$ In the reprint of Michnik's book in 1966, moreover, the figure of Bolotnikov is even erased. Following the insights of the sociologist Hanna Świda-Ziemba, who after the 1956 protests saw that young people were no longer inspired by revolutionary minds, but counted on small changes within the system, we may assume that pupils were more willing to learn such content than their colleagues had previously been. ${ }^{91}$

How the next major reform in history teaching in the middle of the $1960 \mathrm{~s}^{92}$ was debated can be understood by comparing three archived reviews of the manuscript of a new secondary school history textbook written by a Polish historian specialising in the seventeenth century, Adam Kersten. In what follows we will see the effects of the commemoration of 1000 years of Catholicism in Poland in 1966, when Polish authorities had agreed to allow for more national symbolism in historical narratives

87. Ustawa o rozwój systemu oświaty i wychowania z 15 lipca 1961 (See Kosiński, Oficjalne i prywatne życie młodzieży, 144).

88. Ministerstwo Oświaty, Program nauczania liceum ogólnokształcącego (klasy VIII-XI). Historia, (Warszawa: Państwowe Zakłady Wydawnictw Szkolnych, 1965), 3.

89. Helena Michnik, Ludwika Mosler, Historia Polski do roku 1795 [A history of Poland until 1795] (Warszawa: Państwowe Zakłady Wydawnictw Szkolnych, 1956), 226.

90. Ibid., 225.

91. Świda-Ziemba, Młodzież PRL, 302.

92. The reform of education system was implemented in the school year 1966-1967. See Kosiński, Oficjalne i prywatne życie młodzieży, 42. 
in order not to lose control over society. ${ }^{93}$ Żanna Kormanowa criticized Kersten's manuscript because of its failure to include enough Russian history, and because it offered a biased selection of historical actors by depicting, for example, Żółkiewski yet leaving out Marx. ${ }^{94}$ A second, anonymous, reviewer liked the "avoidance of patriotic bombast" ${ }^{95}$, but nevertheless asked for the "positive and progressive facts of our history" to be brought more to the fore so that they could be a "source of national pride." 96 The third reviewer, Jarema Maciszewski, was the editor of the first post-Second World War publication of Żółkiewski's memoirs in $1966 .{ }^{97} \mathrm{He}$ praised the manuscript because it incited pupils to "independent critical historical thinking." ${ }^{98}$ At a meeting of the Ministry of Education, the manuscript was accepted for publication, which shows that hard-line historians in favour of Soviet interpretations of Polish history no longer held sway. ${ }^{99}$

These three visions correspond to the diversity in Polish historiography evident after $1956 .{ }^{100}$ Kersten's presentation of the Time of Troubles in print offers a compromise of these visions. The peasant revolution is said to have been triggered by the hunger of the winter of 1601-1602 and by a rise in serfdom. ${ }^{101}$ As such, this presentation betrays the influence of both the Annales school and Soviet historiography. Kersten's historical reading also presents more historical actors. Whereas Bolotnikov is allowed only a short factual description, Żółkiewski's name is given in bold, with both his fighting in Klushino and his negotiations with the Muscovite boyars given more attention. ${ }^{102}$ Moreover, for the first time after the Second World War, a Polish history schoolbook granted the Polish-Russian war of 1609-1611 comparable attention to the end of the Time of Troubles.

93. Marcin Zaremba, Komunizm, legitymacja, nacjonalizm: nacjonalistyczna legitymizacja władzy komunistycznej w Polsce [Communism, legitimacy, nationalism: nationalist legitimacy of the Communist authorities in Poland] (Warszawa: Instytut Studiów Politycznych Polskiej Akademii Nauk, Wydawnictwo Trio, 2005), 325.

94. AAN MOiSW, 148, 94.

95. Ibid., 76 .

96. Ibid., 148, 74 .

97. Stanisław Żółkiewski, Początek i progres wojny moskiewskiej [The start and progression of the Polish-Moscovite War], ed. Jarema Maciszewski (Warszawa: Państwowy Instytut Wydawniczy, 1966).

98. Jarema Maciszewski, Ocena pracy A. Kerstena i T. Łepkowskiego: Historia dla klasy II liceum ogólnokształcącego [Evaluation of the work of A. Kersten and T. Łepkowski: History for 2nd high school class], AAN MoiSW, 148, 83.

99. Protokół posiedzenia Zespołu Oceniającego w zakresie historii w dniu 15.09.1967 od godz. 9.00 do godz. 10.30 [Minutes of the meeting of the Evaluation Team in the scope of history on 09/15/1967 from 9 AM to 10:30 AM], AAN MOiSW, 148, 118.

100. Stobiecki, Historiografia PRL, 131.

101. Adam Kersten, Tadeusz Łepkowski, Historia dla klasy II liceum ogólnokształcącego [History for 2nd high school class] (Warszawa: Państwowe Zakłady Wydawnictw Szkolnych, 1968), 20 .

102. Ibid., 21. 
The Ministerial programme of 1970 was the next milestone in Polish twentieth century history teaching, as it placed the development of an emotional bond with the Polish nation on the same level of importance as the class struggle. In learning about the past of the Polish nation, pupils needed to "appreciate its successes and noble traditions, understand the causes of its failures and defeats, and identify its development." 103 The programme listed in detail which aspects of the Time of Troubles teachers needed to address. Starting with the "crisis" in the Muscovite Empire at the end of the sixteenth century, next to be discussed was the "peasant war," the "foreign invasion in Russia," and "the supremacy of Poland." This would be followed by "the Battle of Klushino and the capture of Moscow in 1610," and then "the nationwide uprising in Russia and the end of the war (Truce of Deulino)." 104 For the first time in Polish twentieth century history teaching, this presentation of the past offered equal attention to the Russian and the Polish sides.

Remarkably, however, Gierowski's widely used school history textbook tells the events of the early seventeenth century in exactly the same way in the first edition published in 1972 as in the $15^{\text {th }}$ edition published in 1987 . Whereas Gierowski's depiction of the cause of the Time of Troubles, simply mentioning the class struggle of peasants ${ }^{105}$, is less nuanced than Kersten's, his presentation of Stanisław Żółkiewski is more elaborate and heroic, as he stresses, for example, that the hetman had an army of only 7,000 people. ${ }^{106}$ His description of the "national Russian movement" is in line with Kersten's, but his final evaluation is more nuanced. Whereas Kersten had presented an all-mighty Russian Tsardom able to repel all attempts at intervention in domestic affairs and keep its independence, Gierowski argued that the Polish-Lithuanian Commonwealth had experienced territorial gains, but that Ladislaus needed to bid farewell to his aspirations for the tsarist throne. ${ }^{107}$ The textbook did not include the new changes of the Ministerial programme of 1984 . That programme was introduced after the abolition of martial law, when the Polish trade union Solidarność could legally function again and contributed to more criticism of communism being expressed in the public sphere. The programme marked a further evolution away from Soviet ideology. Listing eight purposes of history teaching, a "critical attitude towards various sources of historical knowledge, independent thinking and the elimination of various kinds of myths and falsifications" are

103. Ministerstwo Oświaty i Szkolnictwa Wyższego, Program nauczania liceum ogólnokształcącego (klasy I-IV) Historia [Teaching program for the 1st-4th high school class. History] (Warszawa: Państwowe Zakłady Wydawnictw Szkolnych, 1970), 3.

104. AAN MOiSW, Program nauczania liceum (1970), 122.

105. Józef Gierowski, Józef Leszczyński, Historia dla klasy 2 liceum ogólnokształcącego [History for 2nd high school class] (Warszawa: Wydawnictwa Szkolne i Pedagogiczne 1987), 215.

106. Ibid., 216.

107. Ibid., 217-218; Kersten, Łepkowski S, Historia dla klasy II liceum ogólnokształcącego, 22. 
prioritised, while the "preparation of pupils for creative work for socialist Poland" is mentioned only at the very end. ${ }^{108}$

This discrepancy points to differences in school textbook content and teaching practices over time. After 1968 and throughout the 1970s, in reaction to the consumerism of their parents, Polish youth is said to have felt a need to organize socially in order to search for a deeper intellectual and emotional life. Such pupils may have approached the depiction of the Time of Troubles in their textbooks with more criticism than their older colleagues after $1956 .{ }^{109}$ In the 1980s, more individualisation and diversity in the behaviour of youth can be seen. ${ }^{110}$

The stable school textbook narrative strongly contrasts with evolutions in Polish history writing since the mid-1960s. Jarema Maciszewski described how the noblemen's burgeoning political consciousness provoked centrifugal tendencies. Because they considered the Polish-Lithuanian Commonwealth to be in a weak position, for example, they did not want to pay taxes to fund King Sigismund's expedition in 1609. ${ }^{111}$ Similarly, in his analysis of the Parliament Session of 1611, Janusz Byliński demythologised the euphoria said to have reigned among the nobility after Stanisław Żółkiewski’s victory at Klushino by pointing to the fact that King Sigismund experienced severe difficulties in gathering money for his expedition in 1612. ${ }^{12}$ In the 1980s, Leszek Podhorodecki began the rehabilitation of King Sigismund by presenting him as a wise king who wanted to use colonisation in order to defuse the unrest of the nobility caused by territorial constraints. ${ }^{113}$ These new insights were backed up in the 1990s by the publication of the memoirs of Józef Budziło. An unwavering loyalist, he had accompanied King Sigismund in Smolensk and had provided the King's army with men during the siege of the Kremlin castle in 1612, until the army capitulated out of starvation. ${ }^{114}$

108. AAN MOiSW, 1183, 196-197.

109. Świda-Ziemba, Młodzież PRL, 493.

110. Ibid., 20.

111. Jarema Maciszewski, Polska a Moskwa 1603-1618: opinie i stanowiska szlachty polskiej [Poland and Moscow 1603-1618: the opinions and positions of the Polish nobles] (Warszawa: Państwowe Wydawnictwo Naukowe, 1968), 308.

112. Janusz Byliński, Sejm z roku 1611 [The Sejm of 1611] (Wrocław: Zakład Narodowy im. Ossolińskich 1970), 152,165. For a similar account see: Władysław Czapliński, Władysław IV I jego czasy [Władysław IV Vasa and his times] (Warszawa: Wiedza Powszechna, 1976), 31.

113. Leszek Podhorodecki, Wazowie $w$ Polsce [The Vasa dynasty in Poland] (Warszawa: Ludowa Spółdzielnia Wydawnicza, 1985), 124. Such an idea was not widely shared among other historians. For a typically negative presentation of King Sigismund III in the 1980s see for example Paweł Jasienica, Rzeczpospolita Obojga Narodów [The Polish-Lithuanian Commonwealth] (Warszawa: Państwowy Instytut Wydawniczy, 1989), 301.

114. Józef Budziło, Wojna moskiewska wzniecona i prowadzona z okazji fałszywych Dymitrów od 1603 do $1612 r$. [The Polish-Muscovite War initiated and conducted as a result of false Dimitris from 1603 till 1612], Janusz Byliński and Józef Długosz, eds. (Wrocław: Wydawnictwo Uniwersytetu Wrocławskiego, 1995), 28. Budziło's testimony has been used in the works of: Henryk Wisner, Król i car: Rzeczpospolita i Moskwa w XVI i XVII wieku [King and tsar: The Commonwealth and Moscow in 16th and 17th century] (Warszawa: Książka i Wiedza, 1995), 71; also in: Marek Kubala and Tomasz Ściężor, eds., Moskwa w rękach Polaków: Pamiętniki dowodców i 
Based on new archival findings, post-communist historiography has drastically changed our understanding of the Time of Troubles. Chester Dunning's central argument is that there had not been so much peasant participation during the Time of Troubles. ${ }^{115} \mathrm{He}$ evaluates the Bolotnikov rebellion not as a social revolution of the masses but as a popular uprising in favour of False Dmitry I, who had claimed to be the youngest son of Ivan the Terrible. ${ }^{116}$ The Klushino confrontation is re-evaluated as a four-hour battle, that Żółkiewski was only able to win due to the collusion of many of Russia's supposed allies, such as the Swedish General Jacob de la Garde, who concluded a hasty truce. Contemporary historians are also more sympathetic towards King Sigismund III. According to Dunning, for example, King Sigismund had been careful to avoid provoking conflict with Russia because he had signed a truce with Boris Godunov and was aware of the social unrest he encountered at home. ${ }^{117}$ In the opinion of Wojciech Polar, on the other hand, conquering Smolensk had been important for King Sigismund in order to legitimise his expedition to the nobility that was interested in territorial expansion. He also argues that, although King Sigismund was long believed to have rejected Stanisław Żółkiewski’s proposition to install Ladislaus IV on the tsarist throne, Sigismund had become reconciled to the fact that he himself would not become the tsar. ${ }^{118}$ Recent scholarship has also revealed that Żółkiewski's negotiations with the Muscovite boyars had contributed to the fiasco because he wanted to give up Smolensk and, unable to read Cyrillic, did not know what he had signed. ${ }^{119}$

\section{Conclusion}

The Time of Troubles takes its place in a long line of important Polish-Russian historical encounters, such as Stefan Batory's campaign against Russia in 1577-1582, the partitions of Poland at the end of the eighteenth century, the Polish uprisings in the nineteenth century, the First and Second World Wars, Soviet hegemony over Poland in the Communist era, and, of course, Katyń (both 1940 and 2010). In contrast to the depiction of the other historical encounters

oficerów garnizonu w Moskwie [Moscow in the hands of the Poles: Diaries of commanders and officers of the Garrison in Moscow] (Kraków: Platan, 2005), 15.

115. Dunning, Russia’s First Civil War, 71.

116. Przemysław Gawron, "Bitwa pod Kłuszynem 1610 roku," in Juliusz A. Chrościcki and Mirosław Nagielski, eds., Hołd carów Szujskich [Shuysky Tribute] (Warszawa: Wydawnictwo Neriton, 2012), 23; Wisner, Król i car, 57; Radosław Sikora, Kłuszyn 1610: rozważania o bitwie [Klushino 1610: analysing the battle] (Warszawa: Instytut Wydawniczy Erica: Fundacja Hussar, 2010).

117. Dunning, Russia’s First Civil War, 440.

118. Wojciech Polak, O Kreml i Smoleńszczyznę: polityka Rzeczypospolitej wobec Moskwy w latach 1607-1612 [On Kremlin and Smolensk: the policy of the Commonwealth to Moscow in the years 1607-1612] (Toruń: Towarzystwo Naukowe w Toruniu, 1995), 331.

119. Wisner, Król i car, 58. 
in Polish history school textbooks published during the short twentieth century (from when Poland reappeared on the map of Europe in 1918 until the collapse of communism), the presentation of the Time of Troubles points to the extreme volatility of Polish historical narration. This article presents the differing ways the interplay of historical research and political developments manifested itself in Polish history textbooks over time. Both in the interwar period and after the Second World War, political developments considerably influenced how historical knowledge could make its way to history school textbooks. However, these dynamics took on a different shape in both periods. During the interwar years, the Sanacja regime distilled from the Time of Troubles those messages it considered useful for educating a new generation of citizens. The figure of Hetman Stanisław Źółkiewski was foregrounded as one of the most important embodiments of civic virtues pupils were encouraged to imitate so as to take up responsibility for their Fatherland. In the early days of the Polish communist period, however, his name no longer appeared in textbooks, because the eastward expansion during the Time of Troubles was seen as the nadir of the Polish betrayal of Slavic interests. Polish historians selected certain Polish-Russian encounters, such as the nineteenth century uprisings, and negotiated a rewriting with their Russian colleagues, but allowed the Time of Troubles to be dominated by the Soviet interpretation of class struggle. The first Polish history book analysing Polish-Russian relations during Sigismund III Vasa's reign based on new archival findings was only published after the collapse of communism. In school textbooks however, we discover how despite communist control its depiction remained a volatile compromise between interwar historiographical thinking and Soviet concepts; evident in the element of tolerance being negotiated between Żółkiewski and the Muscovite boyars. From 1956 onwards, narratives of the Time of Troubles gradually move away from Soviet interpretations of history. Hetman Stanisław Żółkiewski appears again in secondary school textbooks, and, in accordance with the Annales school of historical thought, socio-economic evolutions begin to be cited as causes for historical events. Teaching programmes from the Ministry of Education, moreover, gradually push class struggle to the margins and favour independent thinking and the development of an emotional bond with the Polish nation.

\section{Institute for Eastern European History}

University of Vienna

machteld.venken@univie.ac.at

Elise Richter Fellow - Senior Postdoctoral Researcher 